\title{
Drosophila IRBP/Ku p70 corresponds to the mutagen-sensitive mus309 gene and is involved in P-element excision in vivo
}

\author{
Eileen L. Beall and Donald C. Rio ${ }^{1}$ \\ Department of Molecular and Cell Biology, University of California, \\ Berkeley, California 94720-3204 USA
}

\begin{abstract}
The $P$ family of transposable elements in Drosophila transpose by a cut-and-paste mechanism involving double-strand gap repair. We report here that a Drosophila mutagen-sensitive mutant, mus309, contains a mutation in IRBP (inverted repeat binding protein), the Drosophila homolog of the mammalian Ku p70 gene. We show that the repair of double-strand DNA breaks after P-element excision is severely reduced in mus309 mutants using an in vivo assay for P-element transposase activity. In addition, excision products recovered from mus309 mutant embryos by use of a plasmid-based P-element mobility assay contain large deletions, suggesting that IRBP is involved in the repair of double-strand DNA breaks. Our findings provide the first demonstration that a mutation in the IRBP gene affects double-strand DNA break repair and suggest that DNA repair functions are conserved between Drosophila and mammals.
\end{abstract}

[Key Words: DNA repair; P elements; transposition; Drosophila; mutagen sensitivity]

Received December 1, 1995; revised version accepted March 4, 1996.

$P$ transposable elements are a family of mobile DNA ${ }^{1}$ elements found in Drosophila melanogaster. They were originally identified as the causative agents for a group of disorders known as hybrid dysgenesis (for review, see Engels 1989). Full-length, 2.9-kb P elements encode an $87-\mathrm{kD}$ transposase protein that catalyzes transposition (Rio et al. 1986) and a $66-\mathrm{kD}$ repressor of transposition (Misra and Rio 1990). Natural Drosophila populations also carry smaller, internally deleted, nonautonomous elements (O'Hare and Rubin 1983), some of which have been shown to repress transposition in vivo (Rasmusson et al. 1993).

All P elements have 31-bp terminal inverted repeats, 11-bp internal inverted repeats, and unique sequences at both P-element termini that are important for transposition (Mullins et al. 1989). The transposase protein specifically binds to sequences within the P element, near the 3l-bp inverted repeats (Kaufman et al. 1989). Sequences in the outer half of the 31-bp inverted repeats are specifically recognized by a Drosophila protein, IRBP (inverted repeat binding protein) (Rio and Rubin 1988). Genetic and biochemical experiments have outlined a model for transposition in which $P$ elements transpose by a nonreplicative cut-and-paste mechanism involving double-strand gap repair (Engels et al. 1990; Kaufman and Rio 1992). A similar mechanism is used by the bac-

\footnotetext{
${ }^{1}$ Corresponding author.
}

terial transposons $\operatorname{Tn} 7$ and $\operatorname{Tn} 10$ (Bainton et al. 1991; Benjamin and Kleckner 1989).

In the cut-and-paste model of transposition, sequence information is unidirectionally transferred from a donor site to a target site. When the P element excises, it leaves behind a double-strand break at the donor site (Engels et al. 1990; Kaufman and Rio 19921. Repair of the break must occur to prevent chromosome loss. The template for repair can be the sister chromatid, the homologous chromosome, or an ectopically located P element, which can lead to restoration of the P element at the excision site if the template for repair contains the P-element sequence (Engels et al. 1990). The repair process presumably occurs by Drosophila-encoded DNA repair enzymes. Because IRBP interacts specifically with the 31 bp inverted repeats (Rio and Rubin 1988), this protein is a good candidate for a Drosophila-encoded protein involved in P-element transposition.

To investigate the possible involvement of IRBP in P-element transposition, the gene encoding IRBP was isolated (Beall et al. 1994). The IRBP amino acid sequence shows significant homology to the $\mathrm{p} 70$ subunit of the human $\mathrm{Ku}$ autoimmune antigen. $\mathrm{Ku}$ was originally identified in patients with several autoimmune disorders (Mimori et al. 1981; Reeves 1992). The mammalian $\mathrm{Ku}$ is a heterodimer composed of $70-$ and $80-\mathrm{kD}$ subunits. Similar to the mammalian $\mathrm{Ku}$ protein, IRBP is associated with an 80- to 90-kD protein (Jacoby and Wensink 1994; E.L. Beall and D.C. Rio, unpubl.). The mammalian Ku 
heterodimer can bind to free DNA termini in a sequenceindependent manner (Mimori and Hardin 1986; Falzon et al. 1993) as well as site-specifically to internal DNA sites (Knuth et al. 1990; May et al. 1991; Messier et al. 1993). Ku possesses ATPase and DNA helicase activities (Cao et al. 1994; Tuteja et al. 1994). In addition, Ku is the DNA-binding subunit of the DNA-dependent protein kinase (DNA-PK) and can reversibly associate with the 450-kD catalytic component (DNA-PKcs) (Gottlieb and Jackson 1993|. DNA-PK is known to phosphorylate a number of nuclear proteins in vitro, including p53, simian virus $40 \mathrm{~T}$ antigen (SV40 Tag), and Spl (Lees-Miller et al. 1990; Bannister et al. 1993; Gottlieb and Jackson 1993|. More recently, radiation-sensitive mutant mammalian cell lines defective for either the $\mathrm{Ku} 80-\mathrm{kD}$ subunit $(x r s-6 / s x i-3)$ or the DNA-PKcs protein $(V-3 / s c i d)$ have been identified, and both show hypersensitivity to ionizing radiation and exhibit defects in immunoglobulin $V(D) /$ recombination (Rathmell and Chu 1994; Taccioli et al. 1994; Blunt et al. 1995; Boubnov et al. 1995; Finnie et al. 1995; Kirchgessner et al. 1995). Interestingly, the Ku p80 mutants display a defect in both signal and coding joint formation during $V(D) /$ recombination (Taccioli et al. 1994), whereas coding joint formation is affected primarily in the DNA-PKcs/scid mutants (Blunt et al. 1995), suggesting overlapping but distinct roles for the $\mathrm{Ku}$ heterodimer and the DNA-PK in $V(D) /$ recombination.

Genetic screens have identified several excision or postreplication repair-deficient mutants in Drosophila (Boyd and Setlow 1976; Boyd et al. 1976, 1981). One mutation, called mus302 (for mutagen-sensitive 302), causes a severe reduction in the survival of flies that have undergone P-element excision (Banga et al. 1991). Cytogenetic mapping of Drosophila polytene chromosomes localized the IRBP gene to the right arm of the third chromosome at position 86E2-3 (Beall et al. 1994). Another mutagen-sensitive mutant, mus309, was mapped genetically to the same location (Boyd et al. 1981). Here, we report that the mus 309 mutation is a mutation in the IRBP gene. In addition, we provide evidence that IRBP is involved in double-strand DNA break repair and P-element transposition.

\section{Results \\ mus309 mutants are unable to repair double-strand DNA breaks}

It has been shown that several mus mutants in Drosophila are involved in DNA double-strand break repair (Banga et al. 1991). To test whether mus309 mutants are involved in this process, we used a genetic assay involving P-element transposase-induced chromosome breaks. The singed-weak $\left(s n^{w}\right)$ allele of the singed bristle locus contains two small, tandemly arranged $P$ elements inserted into the 5'-untranslated region of the X-linked singed gene (Engels 1979; Roiha et al. 1988) (Fig. 1A) and was used as the source of $P$ elements. When a somatic source of transposase $[\Delta 2-3(99 \mathrm{~B})]$ is provided (Robertson
A

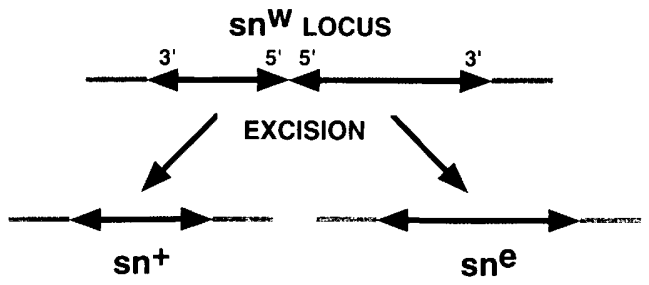

B

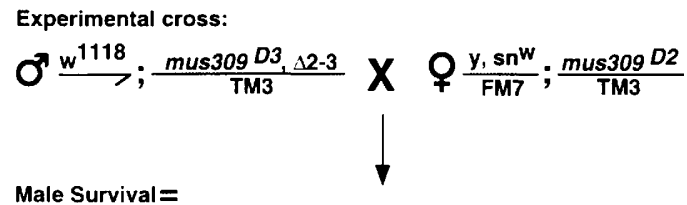

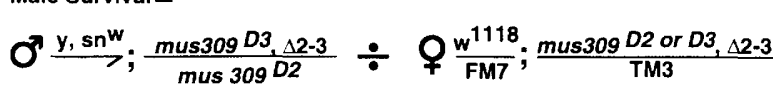

Female Survival=

$\bigcirc \frac{y, s{ }^{w}}{w^{1118}} ; \frac{m u s 309 D 3, \Delta 2-3}{m u s 309^{D 2}} \div \oint \frac{w^{1118}}{F M 7} ; \frac{\text { mus } 309 D 2 \text { or } D 3, \Delta 2-3}{T M 3}$

Control crosses:

mus3091:

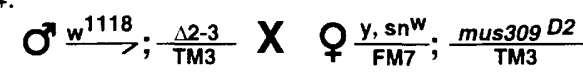

mus 309 without $\Delta 2-3$ :

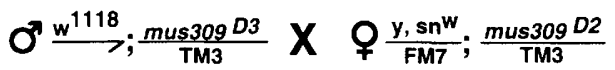

Figure 1. Somatic P-element excision assay. (A) A schematic diagram of the assay used to determine the involvement of mus309 in P-element excision. Two tandemly arranged P elements at the $s n^{u}$ locus are readily mobilized in the presence of P-element transposase. Excision of one element changes the bristle phenotype to singed-extreme $\left(s n^{e}\right)$, whereas excision of the other element changes the phenotype to wild-type $\left(s n^{+}\right)$. P-element mobilization is detected as a mosaic bristle pattern in adult flies. $(B)$ The genetic crosses used to determine the involvement of mus309 in P-element transposition. Male or female survival was determined as the ratio of male or female siblings undergoing P-element mobilization in a mus $309 \mathrm{mu}-$ tant background relative to mus309/TM3 sisters that lacked the $s n^{\prime \prime}$ elements. mus $309 /+$ refers to the control cross in which a single, functional copy of mus309 was present in all progeny. mus 309 without $\$ 2-3$ refers to the control cross performed in the absence of transposase. For all crosses, non-TM3 progeny containing the $s n^{w}$ chromosome and mus309/TM3 female progeny that lacked the $s n^{w}$ chromosome were scored to determine the male or female survival, as diagramed for the experimental cross. (See Materials and methods for details.)

et al. 1988), mobilization of the $s n^{w}$ elements results in a change in the bristle phenotype from $s n^{w}$ to $s n^{+}$/wild type) or $s n^{e}$ (singed-extreme), which is detected as a mosaic bristle pattern in adult flies (Laski et al. 1986). If mus309 is involved in the repair of double-strand DNA breaks after a P element is mobilized, a reduction in the number of mosaic males should be observed in a mus309 mutant background.

Heterozygous males carrying both the mus $309^{D 3}$ allele and the transposase source $(\Delta 2-3)$ on the same third 
chromosome were crossed to heterozygous mus $309^{D 2}$ females carrying the $s n^{w}$ allele (Fig. 1B). It was necessary to perform the test with the mus 309 heteroallelic combination because of the linkage of each mus309 allele to a recessive lethal mutation(s). Control crosses were performed with isogenic strains that were either heterozygous for the mus 309 mutation or lacked the $\Delta 2-3(99 \mathrm{~B})$ transposase (Fig. 1B). The involvement of mus309 in P-element transposition was determined by calculation of the ratio of male progeny carrying the $s n^{w}$ P-elementcontaining chromosome relative to their sisters that lacked the $s n^{w}$ chromosome, in the presence of transposase, as depicted in Figure 1B (male survival). We found a threefold reduction in the survival of mus 309 mutant males that lacked the P-element transposase (Table 1A, cf. lines 1 and 2). However, we found an additional sixfold reduction in the survival of mus $309 \mathrm{mu}$ tant males containing the $s n^{w}$ chromosome in the presence of transposase (Table 1A, cf. lines 2 and 3). Two Drosophila mutants, mei-41 and mus302, showed a similar reduced male survival by this same assay (Banga et al. 1991).

Because the males in this experiment did not have a homologous $\mathrm{X}$ chromosome to serve as a template for gap repair following P-element excision, we examined the effect of P-element mobilization in sibling mus 309 mutant females as diagramed in Fig. 1B to determine whether the presence of an homologous sequence would affect the repair of double-strand breaks in mus $309 \mathrm{mu}$ tants. Female survival was calculated as described in Figure $1 \mathrm{~B}$, and the results are shown in Table 1B. Like the sibling males, there was a slight reduction in the survival of mus309 mutant females that lacked P-element mobilization (1.3-fold decrease; Table 1B, cf. lines 1 and 2). However, there was an additional 1.9 -fold reduction in the survival of mus309 mutant females that had undergone P-element mobilization (Table 1B, cf. lines 2 and 3 ). Moreover, all of the surviving mus 309 mutant females had several interesting phenotypes, including extensive white eye color mosaicism $\left(w^{-}\right)$but normal ommatidial

Table 1. Survival of mus 309 mutant males and females after $P$ element mobilization

\begin{tabular}{|c|c|c|}
\hline Genotype & Percent survival ${ }^{a}$ & Total $^{b}$ \\
\hline & Males & \\
\hline mus309/ + & $56 \pm 7$ & 433 \\
\hline mus309 without $\Delta 2-3$ & $18 \pm 2$ & 439 \\
\hline mus 309 and $\Delta 2-3$ & $3 \pm 0.8$ & 415 \\
\hline & B. Females & \\
\hline mus/309+ & $66 \pm 1 \times 10^{-4}$ & 453 \\
\hline mus309 without $\Delta 2-3$ & $50 \pm 0.2$ & 585 \\
\hline mus 309 and $\Delta 2-3$ & $27 \pm 1 \times 10^{-4}$ & 608 \\
\hline
\end{tabular}

${ }^{a}$ Percent survival is determined as the ratio of mus 309 mutant males/females undergoing P element mobilization vs. mus309/ TM3 sibling sisters lacking $P$ elements $(\times 100)$ as diagramed in Fig. 1B for male/female survival. Mean ratios are shown \pm S.D.

$\mathrm{b}$ The number of flies scored of the genotypes indicated in Fig. $1 \mathrm{~B}$ that were used to determine male/female survival. morphology as well as severe abdominal deformities that are indicative of cell death.

The higher survival of mus 309 mutant females in the $s n^{w}$ assay might result from gap repair following P-element mobilization. However, because mus 309 mutants undergo extensive deletions following a transposase-induced double-strand DNA break (see below), we can suggest an alternative hypothesis. Because the two female $\mathrm{X}$ chromosomes are differentially marked $/ w^{+}$on the $s n^{w}$ chromosome and $w^{1118}$ on the $s n^{+}$chromosome, Fig. 1B), intrachromosomal deletions extending from $s n^{w}$ through the white locus in mus309 mutant females would result in the somatic loss of the $w^{+}$gene on the $s n^{w}$-containing chromosome. These deletions could lead to the observed $w^{-}$mosaic eye color patches in mus 309 mutant females. Deletions of this sort would result in a higher rate of lethality in mus 309 mutant males because of the loss of essential genes located within the deleted regions. Because all of the mus 309 mutant females, but not the control females that had undergone P-element mobilization, displayed the $w^{-}$eye color mosaicism, it appears that gap repair from a homolog in mus $309 \mathrm{mu}-$ tant females is severely impaired. These results demonstrate that the mus 309 gene product is required for the repair of P-element-induced double-strand DNA chromosome breaks, both in the presence or absence of a homologous sequence. The finding that mus $309 \mathrm{mu}-$ tants are hypersensitive to the X-ray mimetic agent methylmethane sulfonate (MMS) (Vogel and Natarajan 1979; Boyd et al. 1981), also supports a role for mus309 in double-strand DNA break repair.

\section{IRBP corresponds to mus309}

We have shown previously that the IRBP gene maps to the interval 86E2-3 on the right arm of the third chromosome (Beall et al. 1994). Interestingly, mus309, a mutation that causes MMS hypersensitivity and female sterility, was mapped genetically to the same genomic region (Boyd et al. 1981). We wanted to determine whether IRBP is mus 309 by testing for complementation of both mus309 mutant phenotypes.

We isolated $\lambda$ genomic DNA clones encompassing the IRBP locus by hybridization with an IRBP cDNA clone (E.L. Beall and D.C. Rio, unpubl.). A restriction map of the region is diagramed in Fig. 2A. We constructed several P-element transformation vectors containing genomic fragments encompassing the IRBP gene. These include 6.8 - and $8.8-\mathrm{kb}$ BamHI fragments, as well as a 13$\mathrm{kb}$ Sall fragment (Fig. 2A). We created a transformation vector containing a deletion in the 13-kb genomic fragment spanning the carboxy-terminal half of IRBP /amino acids 266-631) to serve as a negative control (Fig. 2A, bottom line). The transgenes were introduced into the Drosophila genome by standard P-element-mediated transformation procedures. Several independent transformants for each of the transgenes were isolated and genetically mapped. Three X-linked or second chromosome transformants for each genomic fragment were 
Figure 2. Complementation of the mus309 mutant phenotypes. (A) Diagram of the IRBP-containing transgenes used to test for complementation of the mus $309 \mathrm{mu}$ tant phenotypes. The top line depicts the 13-kb genomic DNA fragment used to construct the various transgenes, with the IRBP location indicated by the bracket. The restriction endonuclease sites are indicated. (S) Sall; (B) BamHI; (A) ApaI. The 1.6-kb $A p a I$ fragment was removed to create a transgene containing a deletion in the carboxyl terminus of IRBP (amino acids 266631, bottom line). A qualitative assessment for the ability of the various transgenes to complement the mus 309 mutant phenotypes is indicated at right. $(B)$ Crosses used to assay for complementation of the mus309 mutant phenotypes by IRBP-encoding transgenes. To determine whether IRBP complemented the mus 309 MMS sensitivity, the ratio of heteroallelic mus 309 mutant progeny containing an IRBP-encoding transgene to siblings heterozygous for the mus309 mutation lexperimental classes, divide the number of male and female progeny from line 1 by line 21 , was compared to the ratio of heteroallelic mus309 mutant progeny lacking an IRBPencoding transgene to siblings heterozygous for the mus 309 mutation (control classes, divide the number of male and female progeny from line 1 by line 2 ) as outlined in the left box. Complementation of the female sterility was determined by crossing heteroallelic mus 309 mutant progeny with or without an IRBP-encoding transgene to wild-type males $\left|w^{111}\right|$ and scoring for progeny as outlined in the right box.

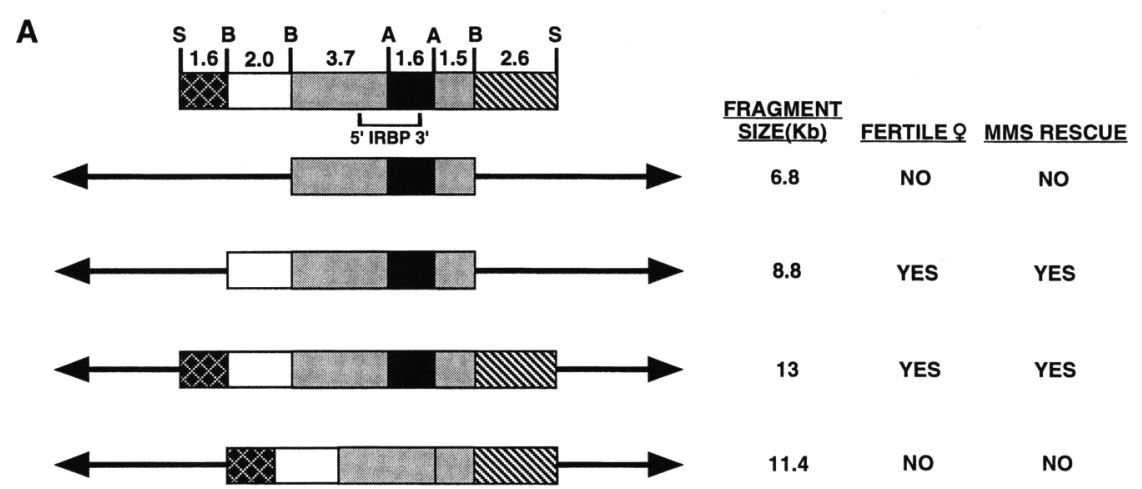

B

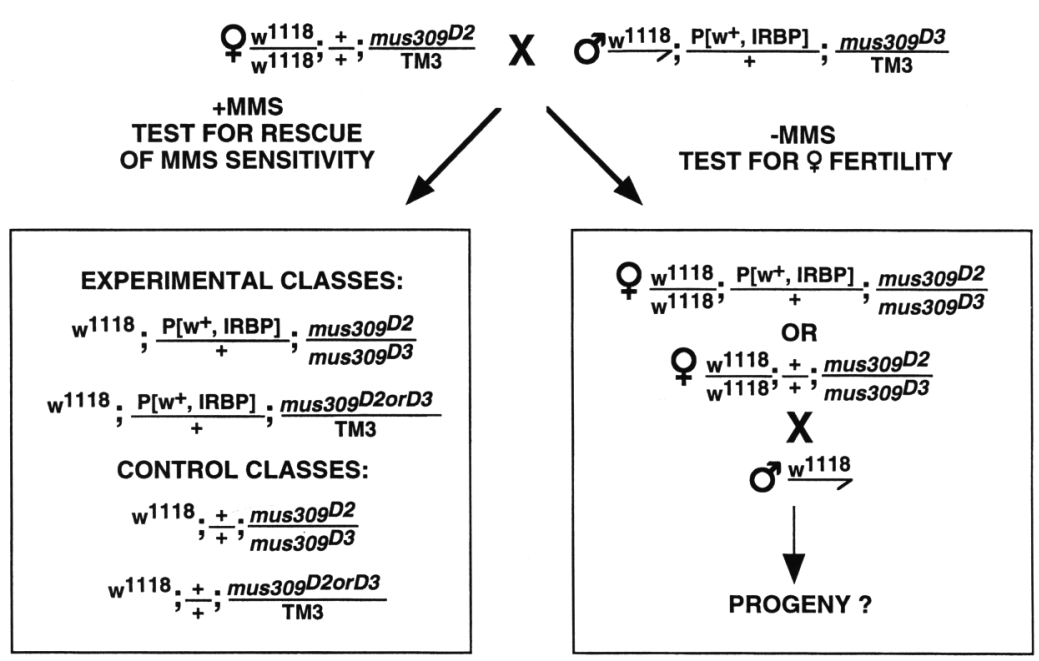

tested for genetic complementation of the mus309 mutant phenotypes, as diagramed in Figure $2 \mathrm{~B}$. The cross outlined in Figure 2B represents the second chromosome transformants. Heterozygous mus $309^{D 2}$ females were crossed to heterozygous mus $309^{D 3}$ males containing an IRBP transgene $\left(\mathrm{P}\left[\mathrm{w}^{+}, \mathrm{IRBP}\right]\right)$ and progeny tested for survival on mutagen-containing food, or for female sterility as discussed below. Because each strain contains a single $I R B P$ transgene, siblings lacking the transgene were used as controls for each cross.

Because mus309 mutant females produce inviable eggs, complementation of female sterility was scored by the presence of larvae in vials after the crossing of heteroallelic mus309 mutant females, either with or without the transgene, to fertile males (Fig. 2B, right box). For each transformant, 100 females were tested for fertility. We found that the 6.8-kb BamHI fragment did not complement the mus 309 female sterility (E.L. Beall and D.C. Rio, unpubl.). Three different transformants containing either the $8.8-\mathrm{kb}$ BamHI or the 13-kb Sall fragments complemented the mus309 female sterility (Table 2). In
Table 2. Complementation of mus309 mutant female sterility with IRBP-containing transgenes

\begin{tabular}{llc}
\hline Transformant $^{\mathbf{a}}$ & Transgene & Percent fertility $^{\mathbf{b}}$ \\
\hline No transgene & & 29 \\
34.1 & $\mathrm{P}\left[\mathbf{w}^{+}\right.$, gIRBP8.8] & 40 \\
121.3 & $\mathrm{P}\left[\mathbf{w}^{+}\right.$, gIRBP8.8] & 49 \\
223.2 & $\mathrm{P}\left[\mathbf{w}^{+}\right.$, gIRBP8.8] & 75 \\
No transgene & & 36 \\
23.1 & $\mathrm{P}\left[\mathbf{w}^{+}\right.$, gIRBP13] & 85 \\
30.2 & $\mathrm{P}\left[\mathbf{w}^{+}\right.$, gIRBP13] & 62 \\
97.1 & $\mathrm{P}\left[\mathbf{w}^{+}\right.$, gIRBP13] & 77 \\
No transgene & & 36 \\
39.1 & $\mathrm{P}\left[\mathbf{w}^{+}\right.$, gIRBP $]$ & 38 \\
\hline
\end{tabular}

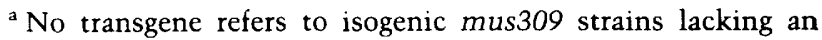
IRBP-encoding transgene. Each number represents an independently isolated transgenic line for the fragment size indicated. ${ }^{b} 100$ females were tested for each transformant. Fertility was scored by the presence of larvae in vials after 7 days. 
the best case, a 2.5-fold increase in female fertility was observed (cf. no transgene with transformant 223.2 for the $8.8-\mathrm{kb}$ transformants). In addition, we found that an IRBP cDNA-containing transformant complemented the mus309 female sterility (E.L. Beall and D.C. Rio, unpubl.) and that a transformant containing a deletion in the IRBP gene would not complement the mus309 female sterility (Table 2). Taken together, these results demonstrate that an ectopic copy of the IRBP gene can partially complement the mus 309 female sterility. Our previous finding that the IRBP transcript level is elevated in females and ovaries is consistent with a role for IRBP in female fertility (Beall et al. 1994).

We also tested whether IRBP-containing transgenes could complement the MMS sensitivity in heteroallelic mus309 mutant flies. We determined the threshold level of MMS that allows for the survival of a few heteroallelic mus309 mutant flies to be between $0.045 \%$ and $0.055 \%$ MMS (Fig. 3, shaded boxes). We tested several concentrations of MMS surrounding this threshold level for complementation of the MMS sensitivity by scoring for survival of heteroallelic mus309 mutant flies in the presence or absence an IRBP-containing transgene when grown on mutagen-containing food (Fig. 2B, left box). We found that the $6.8 \mathrm{-kb}$ BamHI transgene did not complement the MMS sensitivity (E.L. Beall and D.C. Rio, unpubl.). However, we found that three different 8.8 - and $13-\mathrm{kb}$ transgenes complemented the MMS sensitivity. A representative for each transgene is shown in Figure 3. In addition, an IRBP cDNA-containing transgene complemented the MMS sensitivity (E.L. Beall and D.C. Rio, unpubl.). At nearly every concentration of MMS tested, there was an increase in the number of heteroallelic mus309 mutant flies carrying an IRBP transgene, with the best increase in survivability at or near the threshold level. For both the 8.8 - and $13-\mathrm{kb}$ genomic fragments, a maximum sevenfold increase in the survivability of IRBP-encoding transgenic flies was observed. Differences in the level of complementation between transgenes are likely the result of differences in the IRBP expression levels because of position effects at the insertion site. Differences in transgene expression levels are common and have been seen with the Drosophila rosy and C/EBP genes (Spradling and Rubin 1983; Rorth 1994). In addition, transformants containing a deletion in the IRBP gene were not able to survive above background levels at any concentration of MMS tested (Fig. 3, P[gIRBP $\Delta]$ ). The finding that both female sterility and MMS sensitivity in mus309 mutant flies can be complemented by several independent IRBP-containing transgenes, and that a transgene lacking a complete copy of IRBP no longer complement either mutant phenotype, demonstrates that IRBP is mus309.

\section{IRBP rescues the DNA repair defect displayed by mus309 mutant embryos}

Because IRBP is known to interact with the P element 31-bp inverted repeats (Rio and Rubin 1988), and mus309 mutants fail to accurately repair P-element-containing $\mathrm{X}$ chromosomes in the presence of active transposase, we directly examined the products of DNA repair following P-element excision in mus 309 mutant embryos. We used a P-element mobility assay in which excision events can be detected by antibiotic resistance selection in bacteria after recovery of the transposition products from Drosophila embryos (Rio et al. 1986; O'Brochta et al. 1991). In this assay a reporter plasmid containing a P-element insertion into the kanamycin resistance gene was used to detect excision events in the presence of transposase (pISP-2/Km, Fig. 4). We used a plasmid containing the transposase gene with the third intron removed (PA2-3) under the control of the Drosophila actin promoter as a

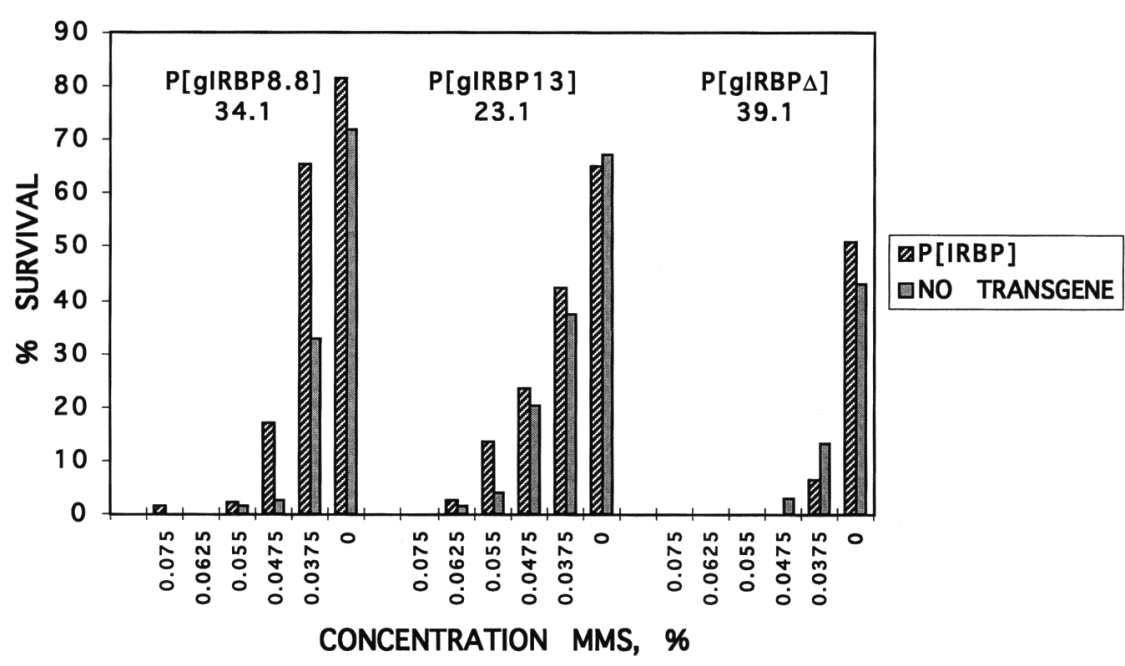

Figure 3. Complementation of mus309 MMS sensitivity by IRBP-encoding transgenes. Fifteen pairs of flies for each transgene were allowed to lay for $48 \mathrm{hr}$ before the parents were removed and mutagen applied to the food. All classes of progeny were counted until 17 days after the cross was initiated. For each concentration of MMS, $\sim 300$ flies were counted. Complementation was determined from the cross indicated in Fig. 2B (left box). The percent survival was calculated as the number of heteroallelic mus309 mutant progeny with (hatched bar) or without (shaded bar) an ectopic copy of IRBP relative to siblings that were heterozygous for the mus309 mutation $\times 100$. Three independent transformants were tested for each transgene, and one representative for each transgene tested is diagramed. (gIRBP) Genomic fragment encompassing the $I R B P$ locus of the size indicated; (gIRBPA) genomic fragment with a deletion in the carboxyl terminus of IRBP. 


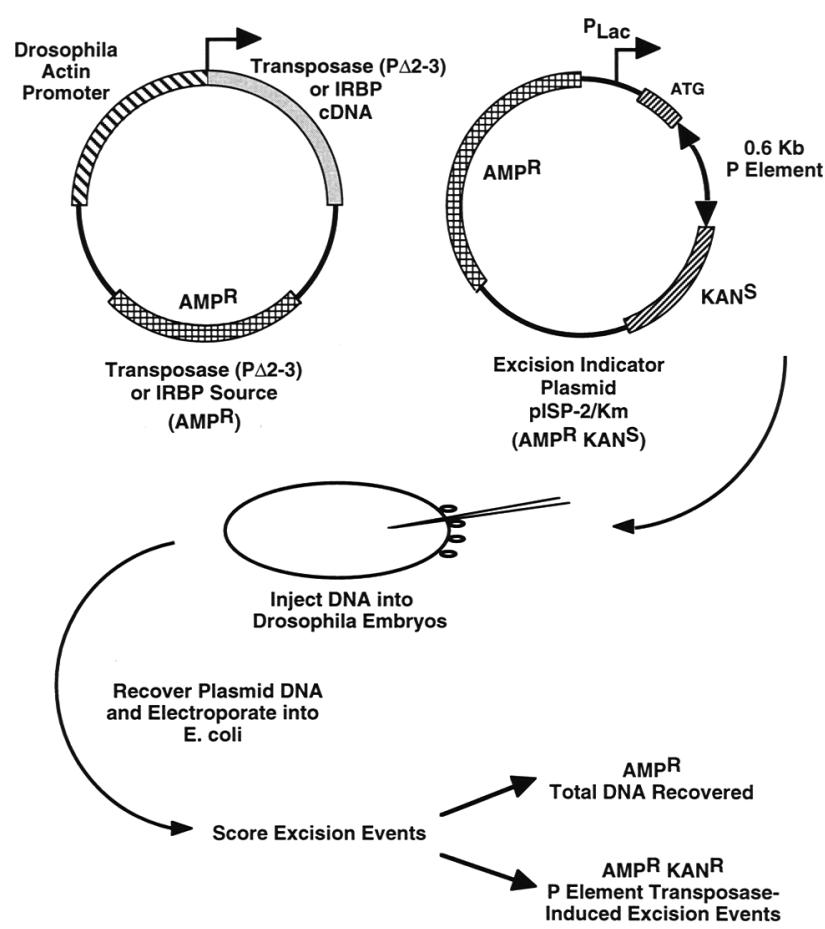

Figure 4. Plasmid-based P-element mobility assay. Schematic diagram of the assay. The excision indicator plasmid (pISP-2/ $\mathrm{Km}$ ) was injected alone or in conjunction with the P-element transposase-encoding plasmid $(\mathrm{P} \Delta 2-3)$, in the presence or absence of the IRBP-encoding plasmid, into $w^{1118}$ (wild-type) or mus309 mutant embryos (see Materials and methods for details). Excision events were determined by the gain in kanamycin resistance $\left(\mathrm{Kan}^{\mathrm{R}}\right)$ after plasmid recovery from injected embryos and electroporation into $E$. coli.

source of transposase. In addition, as a source of IRBP in the assay, we used a plasmid containing the IRBP CDNA under the control of the Drosophila actin promoter. If IRBP is required for P-element excision in vivo, then the observed reporter plasmid excision frequency in the presence of P-element transposase may be reduced in mus309 mutant embryos and should be restored by a cDNA encoding IRBP.

We injected the reporter plasmid alone or in combination with the transposase plasmid, as well as with or without the IRBP plasmid, into either wild-type or mus309 mutant, preblastoderm embryos by standard microinjection techniques. Plasmid DNA was recovered and introduced into bacteria. Excision events were detected by the gain of kanamycin resistance (Fig. 4). Because the $\mathrm{P}$ element interrupts the coding region of the kanamycin-resistance gene, only excisions that restore the open reading frame will be detected in this assay. In fact, we will only recover excised plasmids that contain small deletions that do not extend into the kanamycinresistance gene or promoter region. We found nearly a 20 -fold reduction in the recovery of excised plasmids in mus309 mutant embryos when compared to wild-type $\left(w^{118}\right)$ embryos (Table 3 , cf. lines 3 and 7$)$. When the plasmid encoding IRBP was injected with both the re- porter and transposase source, we found a 10-fold increase in the excision frequency in mus309 mutants (Table 3 , cf. lines 7 and 8 , which represents $\sim 30 \%$ of the wild-type excision frequency (Table 3 , cf. lines 4 and 8). In separate experiments in which the concentration of IRBP was doubled, up to $50 \%$ of the excision frequency was restored (E.L. Beall and D.C. Rio, unpubl.). Similar frequencies have been reported for the mammalian $\mathrm{Ku}$ p80 subunit in restoring coding joint formation during $V(D) /$ recombination in the xrs-6 mutant cell line (Taccioli et al. 1994). It is interesting to note that we found a stimulation in the excision frequency in wild-type embryos when IRBP was injected with both the reporter and transposase source (Table 3 , cf. lines 3 and 4). Increased levels of IRBP may protect the broken DNA ends from exonuclease digestion after the $P$ element excises (see Discussion|. The finding that the mammalian $\mathrm{Ku} \mathrm{p} 70$ subunit alone has DNA end-binding activity (Messier et al. 1993) is consistent with this hypothesis.

To determine the nature of the excision products, we analyzed the DNA recovered from ampicillin/kanamycin-resistant plasmids after excision in both wild-type and mutant embryos by restriction endonuclease digestion. We found that a DNA fragment encompassing the excision site was highly variable in size in plasmids recovered from mus309 mutant embryos, suggesting a defect in the correct processing of the DNA termini after the excision event. In addition, plasmids in which IRBP was injected with both the reporter and transposase source showed a restoration in the uniformity of the fragment size, similar to the size found from wild-type embryos, suggesting that IRBP was restoring the defect in the mus309 mutant embryos (E.L. Beall and D.C. Rio,

Table 3. Frequency of P element excision in embryos

\begin{tabular}{|c|c|c|}
\hline $\begin{array}{l}\text { Embryo } \\
\text { type }\end{array}$ & Plasmid injected ${ }^{a}$ & $\begin{array}{l}(\operatorname{Amp}+\mathrm{Kan}) / \\
\operatorname{Amp}\left(\times 10^{5}\right)^{\mathrm{b}}\end{array}$ \\
\hline$w^{1118}$ & pISP-2/Km & $0.40 \pm 0.3$ \\
\hline$w^{1118}$ & pISP-2/Km + IRBP & $0.27 \pm 0.06$ \\
\hline$w^{1118}$ & $\mathrm{pISP}-2 / \mathrm{Km}+\mathrm{P}\lrcorner 2-3$ & $5.2 \pm 1.0$ \\
\hline$w^{1118}$ & $\mathrm{pISP}-2 / \mathrm{Km}+\mathrm{IRBP}+\mathrm{PA} 2-3$ & $6.5 \pm 0.2$ \\
\hline mus $309^{D 2} D .3$ & $\mathrm{pISP}-2 / \mathrm{Km}$ & $0.31 \pm 0.3$ \\
\hline mus $309^{D 2} D .3$ & pISP-2/Km + IRBP & $0.28 \pm 0.3$ \\
\hline mus $309^{D 2} D .3$ & $\mathrm{pISP}-2 / \mathrm{Km}+\mathrm{P} \Delta 2-3$ & $0.21 \pm 0.3$ \\
\hline mus $309^{D 2} D 3$ & $\mathrm{PiSP}-2 / \mathrm{Km}+\mathrm{IRBP}+\mathrm{P} \Delta 2-3$ & $2.1 \pm 0.3$ \\
\hline
\end{tabular}

All injections were performed with the same set of flies. One hundred seventy embryos were injected for each plasmid mixture. DNA was recovered, and 35 embryo equivalents electroporated into $E$. coli to score for $P$ element excision events as diagramed in Fig. 4.

a (pISP-2/Km) The P element-containing reported plasmid; (IRBP) the IRBP cDNA-encoding plasmid pBSKS|+|PAcIRBP; $\mid \mathrm{P}\lrcorner 2-3 \mid$ the transposase-encoding plasmid pBSKS|+|PAcKP$\mathrm{S} \Delta 2-3$.

$\mathrm{b}$ The ratio of excised plasmids vs. the total number of plasmids recovered, including the reporter pISP- $2 / \mathrm{Km}$, the transposase-, and IRBP-encoding plasmids. Mean ratios are shown \pm S.D. for experiments that were performed at least three times. 
unpubl.). DNA sequence analysis of these plasmids confirmed our findings from the restriction endonuclease analysis (Fig. 5). We found that $50 \%$ of the kanamycinresistant plasmids recovered from mus 309 mutant embryos in the absence of IRBP had extensive regions of the kanamycin-resistance gene deleted [Fig. 5, sequence block 2 (mus)], whereas $<10 \%$ of the plasmids recovered from wild-type embryos had minor deletions [Fig. 5, blocks 1 and $3\left(w^{118}\right.$ and $w+$ IRBP $)$. More importantly, plasmids recovered from mus 309 mutant embryos in the presence of IRBP had sequences comparable to sequences recovered from wild-type embryos [Fig. 5, cf. sequence block $3(\mathrm{M}+\mathrm{IRBP})$ with block $\left.1\left(\mathrm{w}^{118}\right)\right]$.

Nearly all of the excision products recovered from wild-type embryos contained both copies of the 8-bp target site duplication and up to 7 nucleotides derived from the P-element 31-bp inverted repeat sequences (Fig. 5, blocks 1 and 4). Similar findings have been reported previously in the sequence analysis of P-element excision products from both a plasmid-based assay (Rio et al. 1986; O'Brochta et al. 1991) and from chromosomal excision events (Takasu-Ishikawa et al. 1992; Staveley et al. 1995). It is possible that transposase makes a staggered cleavage at each $5^{\prime}$ end of the 8 -bp target site. Gap repair from another P-element-containing molecule can result in P-element-derived sequences left at the donor site after excision (see Discussion). A clear picture regarding the mechanism of P-element excision will re- quire a better understanding of the exact nature of the DNA cleavages made by P-element transposase.

Our results demonstrate that the processing of doublestrand DNA breaks after P-element excision is severely affected in mus309 mutant embryos. In addition, the finding that the IRBP cDNA can partially restore the excision frequency and totally restore the precision of donor site repair in mus 309 mutant embryos shows that the DNA repair defect observed in mus309 mutant embryos is caused by a mutation in the $I R B P$ gene.

\section{Discussion \\ Drosophila proteins are required for P-element transposition}

Several prokaryotic transposons demonstrate a requirement for host-encoded proteins to facilitate transposition (for review, see Berg 1989; Kleckner 1989; Pato 1989|. Here, we show an important role for the Drosophila protein IRBP in double-strand DNA break repair after P-element transposition. We found that a DNA repair-deficient Drosophila mutant, mus309, is unable to repair P-element-induced double-strand DNA breaks and that $I R B P$ is mus309. In addition to repair of site-specific cleavages after P-element mobilization, our results suggest that IRBP is necessary for the repair of DNA breaks induced by DNA-damaging agents such as MMS.

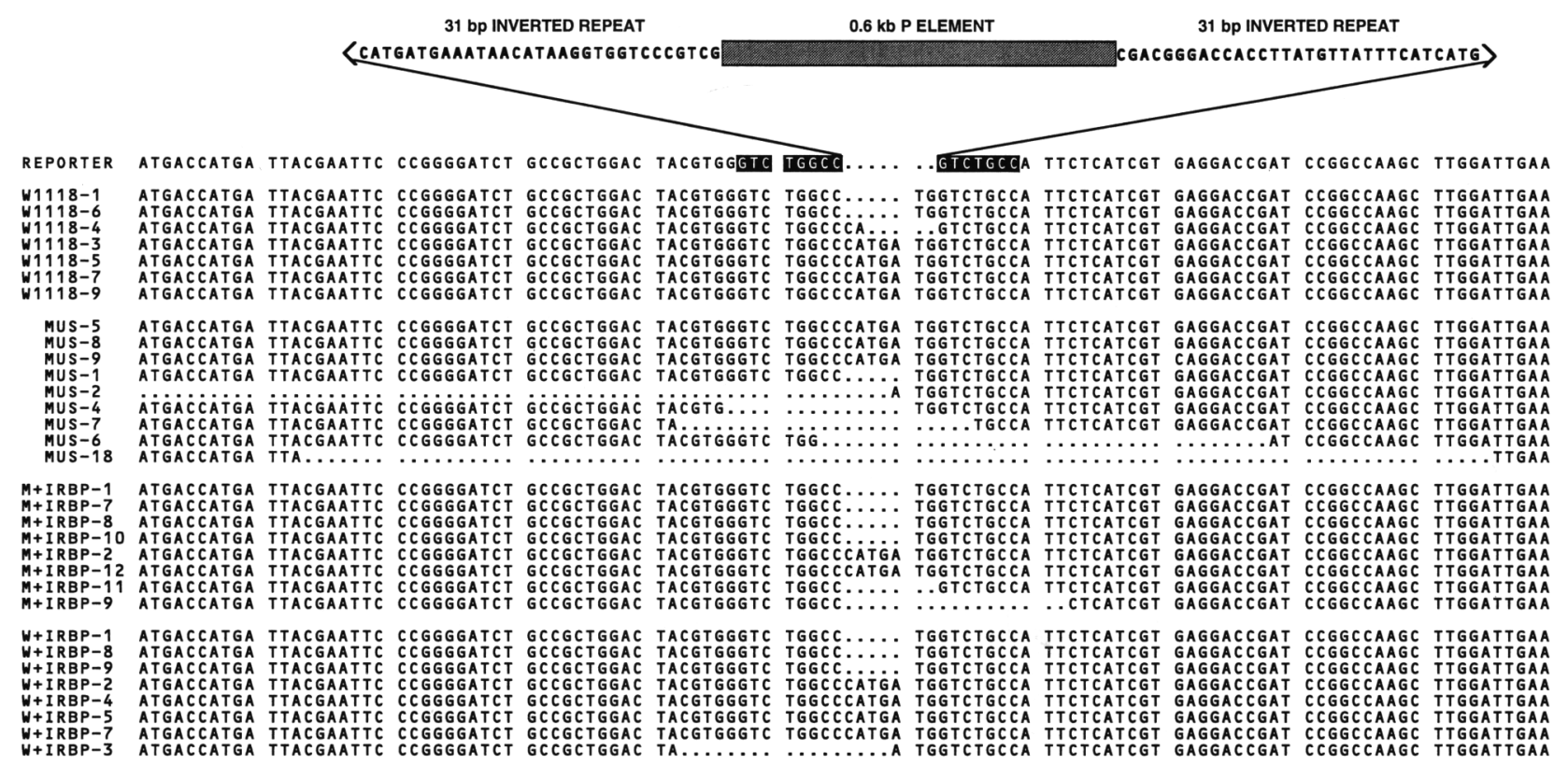

Figure 5. DNA sequence analysis of excised plasmids recovered from $w^{1118}$ (wild-type) and mus309 mutant embryos. A partial nucleotide sequence of pISP-2/Km (reporter) is shown, including the 0.6-kb P element (shaded box), the 31-bp inverted repeats, the 8-bp target site duplication (black-boxed letters), and 88-bp surrounding the excision site. The right 8 -bp target site duplication is missing 1 nucleotide, as has been described previously (O'Brochta et al. 1991). (.) Deletions in the above sequences. The first sequence block $\left(w^{1118}\right\}$ represents sequences of $\mathrm{Kan}^{\mathrm{R}}$ plasmids recovered from wild-type embryos in the presence of transposase only. The second sequence block (mus) represents sequences of $\operatorname{Kan}^{\mathrm{R}}$ plasmids recovered from mus 309 mutant embryos in the presence of transposase only. The third sequence block $\left(\mathrm{M}+\mathrm{IRBP}\right.$ ) represents sequences of $\mathrm{Kan}^{\mathrm{R}}$ plasmids recovered from mus 309 mutant embryos after coinjection of the IRBP-containing plasmid. The fourth sequence block (W + IRBP) represents sequences of Kan ${ }^{R}$ plasmids recovered from wild-type embryos after coinjection of the IRBP-containing plasmid. 
Because IRBP shows significant protein sequence homology to the $70-\mathrm{kD}$ subunit of the mammalian $\mathrm{Ku}$ autoimmune antigen (Beall et al. 1994) our findings provide the first in vivo analysis of a Ku $70-\mathrm{kD}$ homolog and demonstrate its involvement in P-element transposition and DNA repair. These results are consistent with the participation of the $\mathrm{Ku}$ heterodimer in double-strand DNA break repair and immunoglobulin $V(D) /$ recombination in mammalian cells (Rathmell and Chu 1994; Taccioli et al. 1994), as well as its DNA-binding characteristics (Mimori and Hardin 1986; Falzon et al. 1993). It is unclear whether $\mathrm{Ku}$ has a direct or indirect role in the repair of double-strand DNA breaks. Ku may simply be protecting the broken ends from exonuclease activity as seen with the gam protein of phage Mu (Akroyd et al. 1986; Thaler et al. 1987). Alternatively, Ku may promote the joining of double-strand DNA breaks by modulating the activity of other repair proteins, such as the human replication protein $\mathrm{A}$ (RPA), through its interaction with DNA-PK (Gottlieb and Jackson 1993). RPA is required in vitro for mammalian nucleotide excision repair (Aboussekhra et al. 1995), and the p34 subunit of RPA is efficiently phosphorylated by DNA-PK in a DNA-dependent manner (Brush et al. 1994; Pan et al. 1994). In addition, p34 becomes phosphorylated in mammalian cells that have been exposed to ionizing or ultraviolet irradiation, possibly linking RPA phosphorylation to a delay in cell-cycle progression until the DNA damage can be repaired (Liu and Weaver 1993; Carty et al. 1994).

The kinase recognition sequences for DNA-PK have been identified for the substrate $\mathrm{p} 53$ and were found to be either serine or threonine residues when adjacent to glutamine (Lees-Miller et al. 1992). There are seven of these potential phosphorylation sequences in the first 144 amino acids of the P-element transposase protein (Rio et al. 1986). We found that an amino-terminal fragment of the transposase protein encompassing these seven potential phosphorylation sites is phosphorylated by the mammalian DNA-PK only in the presence of double-stranded DNA (Y.M. Mul, E.L. Beall, and D.C. Rio, unpubl.). Furthermore, DNA-PK activity has been reported in Drosophila (Finnie et al. 1995). It is conceivable that the breaks in DNA after cleavage by transposase may trigger the phosphorylation of transposase by $\mathrm{Ku}$ / DNA-PK to allow release of the complex from the DNA and/or direct repair of the breaks by the Drosophila repair machinery. It is not known, however, what role, if any, phosphorylation of the transposase protein may have in transposition.

Our finding that large deletions occur after a P element excises in the absence of IRBP (Fig. 5) supports a role for IRBP similar to the mammalian Ku protein in doublestrand DNA break repair. Addition of IRBP in the injection assay restores the joining of the DNA termini, as demonstrated both by excision frequency (Table 3) and DNA sequence analysis (Fig. 5). Because IRBP is associated with an 80 - to $90-\mathrm{kD}$ protein corresponding to the mammalian $\mathrm{Ku} 80-\mathrm{kD}$ subunit (Jacoby and Wensink 1994; E.L. Beall and D.C. Rio, unpubl.), we are not sure whether IRBP alone is providing the repair functions or whether there is a free pool of the $80-$ to $90-\mathrm{kD}$ subunit present that can interact with IRBP. Recently, the mammalian $\mathrm{Ku} 80-\mathrm{kD}$ subunit was reported to be unstable in the absence of the 70-kD subunit (Satoh et al. 1995). In addition, the mammalian $\mathrm{Ku} 70-\mathrm{kD}$ subunit alone can bind to DNA in a manner similar to the $\mathrm{p} 70 / \mathrm{p} 80$ heterodimer (Messier et al. 1993; Wang et al. 1994). These findings, along with the observation that IRBP binds site specifically to the 31-bp inverted repeats (Rio and Rubin 1988), suggest that IRBP alone may have a function in repair of P-element-induced double-strand DNA breaks. It is interesting to note that the mammalian $\mathrm{Ku}$ heterodimer possesses both ATPase and DNA helicase activities (Cao et al. 1994; Tuteja et al. 1994). It is possible that one function for IRBP may be to unwind the DNA helix to facilitate interaction with RPA and trigger extension of the broken ends by the polymerase during gap repair.

\section{P-element excision mechanism}

A mechanism for P-element transposition that is based on several genetic and biochemical experiments has been proposed. In this model, a double-strand DNA break is left at the donor site after a P element is excised (Engels et al. 1990; Kaufman and Rio 1992). Following excision, templated repair from either a homologous chromosome, sister chromatid, or ectopic sequence located elsewhere in the genome leads to restoration of the original target sequence, restoration of the P element at the excision site, or partial restoration of the P-element sequence (Engels et al. 1990). It is thought that the gap repair after a $P$ element is excised may occur after DNA synthesis (during late $S$ or $G_{2}$ in the cell cycle), when the sister chromatid may serve as a template for repair of the DNA break (Engels et al. 1990). However, the exact nature of the initial cleavage events prior to excision of the $P$ element from the donor site is unknown. It is not known whether transposase makes a staggered or bluntended cleavage during excision.

Our plasmid sequencing data show that in nearly all plasmids analyzed from $w^{1118}$ embryos, both target site duplications and up to 7 additional $P$ element 31 -bp inverted repeat-derived nucleotides are left behind at the donor site (Fig. 5). Similar findings have been reported previously in the sequence analysis of excised $P$ elements with a similar plasmid excision assay (Rio et al. 1986; O'Brochta et al. 1991), or from P elements excised from chromosomal locations (Takasu-Ishikawa et al. 1992; Staveley et al. 1995). In the sequence analysis of excision events from chromosomally located $P$ elements at the vestigial $(v g)$ locus, however, the majority of cases showed that 15-19 bp derived from the 31-bp inverted repeats remained at the excision site /Staveley et al. 1995|. The difference between the extent of the sequence remaining at the donor site may reflect a difference in the assays.

Previous models attempting to explain the occurrence of the extra P-element-derived sequences at the donor site propose either a staggered cleavage within the P-element termini (Staveley et al. 1995) or the formation of 
a hairpin intermediate during excision (Takasu-Ishikawa et al. 1992). Neither model can adequately account for the variation in the sequences left behind at the donor site or the retention of the integrity of the excised P-element termini. Occasionally P-element excision events lead to extensive deletions of DNA sequences flanking the insertion site. Perhaps mus 309 mutants will allow for the creation of enlarged deletions extending from the insertion site into the flanking DNA to facilitate the generation of null mutations in nearby Drosophila genes. Our results from both the $s n^{w}$ experiments and the plasmid excision experiments support this possibility. The $w^{-}$eye color mosaicism observed in mus309 mutant females that have undergone P-element mobilization can be explained by the creation of large deletions surrounding the excision site in the absence of mus309/ IRBP.

On the basis of these data and a model for transposition in plants (Saedler and Nevers 1985), we propose that the cleavage pattern made by transposase is staggered, with precise cleavages made at each $5^{\prime}$ end of the target site duplication and $3^{\prime}$ end of the P element 31 -bp inverted repeat. Precise excision would result from the annealing of the staggered ends in the absence of gap repair. However, gap repair using the free $3^{\prime}$ termini would lead to the copying of information from another P-elementcontaining molecule. Depending on the length of the segment copied, a replacement of the target site duplication, along with sequences extending into the transposon termini, would be observed. This model would explain the observed excision products, including the retention of both 8-bp target site duplications (Fig. 5, block 3 , line M+IRBP-9), the copying of sequences from a single 31-bp inverted repeat (Fig. 5, block 1, $w^{1118}-1,6$, and 4 ), as well as the copying of sequences from both 31 -bp inverted repeats (Fig. 5, block 1, $w^{1118}-3,5,7$, and 9). In addition, if an exonuclease were to bind to the free $3^{\prime}$ end prior to polymerase binding, small deletions would be generated (Fig. 5, block 4, w+IRBP-3). A similar staggered cleavage pattern has been observed for the prokaryotic transposon $\operatorname{Tn} 7$ (Bainton et al. 1991). Once the exact nature of the DNA cleavages by transposase is determined, a more precise mechanism explaining the excision reaction can be formulated.

\section{Conservation of repair mechanisms in eukaryotes}

$\mathrm{Ku}$ homologs have been reported in several organisms, including mouse, monkey, hamster, and Drosophila (Paillard and Strauss 1991; Falzon and Kuff 1992; Beall et al. 1994; Jacoby and Wensink 1994; Rathmell and Chu 1994). In addition, a putative Ku homolog has been reported in the budding yeast, Saccharomyces cerevisiae (Feldmann and Winnacker 1993). DNA-PK activity has been reported for mouse, hamster, Xenopus, and Drosophila through the use of in vitro peptide kinase assay (Finnie et al. 1995). Mutations in either the $\mathrm{Ku} 80-\mathrm{kD}$ or DNA-PK genes for mouse, hamster, and humans show extreme hypersensitivity to ionizing radiation and display defects in immunoglobulin $V(D) /$ recombination in mammalian tissue culture cells (Rathmell and Chu 1994; Blunt et al. 1995; Lees-Miller et al. 1995; Peterson et al. 1995). Our finding that the Drosophila Ku p70 mutant mus 309 has similar phenotypic defects as the mammalian mutant cell lines strongly suggests that the functions of the Ku/DNA-PKcs proteins are conserved in eukaryotes.

P elements have been used extensively as vectors for germ-line transformation in Drosophila. This procedure allows for the integration of single copies of DNA segments into the genome without duplications or rearrangements. In addition, $\mathrm{P}$ elements have been used for insertional mutagenesis studies and for $l a c Z$ enhancer trapping. It would be useful for P-element transposition to occur in other organisms in which gene manipulation is difficult. Previous experiments have demonstrated that P-element transposase can catalyze excision events in mammalian and yeast cells by a plasmid excision assay (Rio et al. 1988). However, attempts at detecting reinsertion of $\mathrm{P}$ elements into a second target DNA segment (forward transposition) have been unsuccessful. DNA repair is required at the donor site after P-element excision and at the insertion site after integration. It is possible that the heterologous mammalian and yeast $\mathrm{Ku}$ complexes cannot function at the target site during integration or are unable to modify transposase activity appropriately following excision. The finding that the Drosophila IRBP and the mammalian and yeast $\mathrm{Ku} p 70$ subunits are only $23 \%$ and $18 \%$ identical, respectively (Beall et al. 1994), suggests that the required Drosophila factors for transposition may have diverged to an extent that no longer allows productive transposition in these heterologous organisms, even though there is a general functional conservation of the Ku subunits and DNA-PK between Drosophila and mammals. Perhaps introduction of the Drosophila genes into heterologous cell types may permit forward transposition.

\section{Materials and methods}

Drosophila strains

The Drosophila strains $w^{1118}$ and $w^{1118} ; T M 3 / C X D$ are as described (Ashburner 1989). The strains FM7a y $y^{31 d} s c^{8} w^{a} v B$ (Bloomington Stock Center), y $s n^{w}$ (Roiha et al. 1988), TM3 $r y^{R K} / r y^{S O 6}$ (Karess and Rubin 1984), and $S b r y^{506} \mathrm{P}\left[\mathrm{ry}^{+} \Delta 2\right.$ 3](99B)/TM6B (Robertson et al. 1988) were used in the $\mathrm{sn}^{\mathrm{w}}$ assay. The strains $w^{1118}$; st mus $309^{D 2} / T M 3$ and $w^{1118}$; mus $309^{D 3}$ $r y / T M 3$ were made by the crossing of $w^{1118} ; T M 3 / C x D$ females to st mus $309^{D 2} / T M 3$ Sb Ser or mus $309^{D 3}$ ry/TM3 Sb Ser (Boyd et al. 1981/ males and selection of white-eyed, stubble bristle, straight-winged flies, and then mating these progeny back to $W^{1118} ; T M 3 / C x D$ females to obtain a balanced stock. Flies were raised on standard cornmeal, molasses, and yeast medium at $25^{\circ} \mathrm{C}$.

\section{Recombinant DNA}

The $\mathrm{P}\left[\mathrm{w}^{-}\right.$, gIRBP $]$elements used in germ-line transformation experiments were constructed by use of pW8 P-element transformation vector (Klemenz et al. 1987). DNA isolated from $\lambda$ FIX genomic clones encompassing the IRBP locus was cleaved 
with Sall to generate a 13 -kb fragment and inserted into Xholcleaved pW8. The 13-kb-containing plasmid was then cleaved with BamHI to yield a 6.8 - or 8.8 -kb fragment that was inserted into BamHI-cleaved pW8 to generate the $6.8 \mathrm{-kb}$ - or $8.8 \mathrm{-kb}$-containing transformation vectors. The transformation vector containing a deletion in the IRBP gene was constructed as follows: The pW8-gIRBP 13-kb Sall fragment-containing plasmid was cleaved with either $X b a I$ and $A p a I$ to generate a $4.1-\mathrm{kb}$ fragment or SalI and ApaI to generate a 7.3-kb fragment. Both fragments were inserted into pw 8 cleaved with $X h O I$ and $X b a I$ to generate a vector containing a $1.6-\mathrm{kb}$ deletion eliminating the carboxyl terminus of IRBP (amino acids 266-631).

The plasmids used in the P-element excision assay were constructed as follows: pISP-2/Km was derived from pISP-2 (Rio et al. 1986) in which pISP-2 was cleaved with PstI and treated with T4 DNA polymerase. Plasmid pKm 109-9 (Reiss et al. 1984) was cleaved with BamHI and HincII and treated with mung bean nuclease and the NPTII (neomycin phosphotranferase kanamycin resistance gene/ fragment inserted into the flush pISP-2 vector, in place of the $l a c Z \alpha$ fragment. pHSX-PAc KP-S $\lrcorner 2-3$ was prepared with pHSX (Jones and Rubin 1990), a 2.6-kb actin 5C fragment from pPAc (Ashburner 1989), a fragment of the transposase gene carrying an amino-terminal portion chemically resynthesized to alter codon usage (D.C. Rio, unpubl.l, and a carboxy-terminal fragment carrying the IVS3 lintervening sequence 3 ) deletion, $\Delta 2-3$ (Laski et al. 1986). pHSX-PAc KP-S $\$ 2-3$ was cleaved with NotI and a $6.5-\mathrm{kb}$ fragment containing the Drosophila actin promoter and the transposase gene was inserted into NotI-cleaved pBSKS|+ | (Stratagene) to make the transposase helper, pBSKS|+|PAc KP-S 2 2-3. To make the IRBP expression plasmid, pNB40 9-1 (Beall et al. 1994) was cleaved with HindIII and filled with the Klenow fragment of DNA polymerase I. The plasmid was then cleaved with NotI to generate a $2.2 \cdot \mathrm{kb}$ fragment containing the IRBP cDNA. In addition, pPAc (Ashburner 1989) was cleaved with BamHI, filled with the Klenow fragment of DNA polymerase I, and cleaved further with NotI, to generate a $2.6-\mathrm{kb}$ fragment containing the Drosophila actin promoter. Both fragments were inserted into NotI-cleaved pBSKS| + |, generating pBSKS| + |PAc IRBP.

\section{P-element transformation}

Transformation of $w^{1118}$ strains was by standard procedures (Spradling 1986), except that the helper plasmid phs $\pi \Delta 2-3$ was used (D.C. Rio, unpubl.). Isolines were established from individual independent transformants. Flies from each line were crossed to balancer strains, after genetically mapping the chromosome into which the element had integrated to establish balanced stocks. DNA blot hybridization was used to confirm that each strain contained a single, intact P-element insertion.

$\mathrm{sn}^{\mathrm{w}}$ assay

The $w^{1118}$; mus $309^{D 3}$ ry $\Delta 2-3(99 \mathrm{~B}) / T M 3$ stock was made by the crossing of mus $309^{D 3} r y / T M 3 S b$ Ser females to $S b r y^{506}$ $\mathrm{P}\left[\mathrm{ry}^{+} \Delta 2-3\right](99 \mathrm{~B}) / T M 6 B$ males and selection of females that were $r y^{+}, \mathrm{Sb}$, non-TM6B. These females were crossed to TM3 ry $\mathrm{rK}^{R K}$ ry ${ }^{506}$ males, and males that were $r y^{+}, \mathrm{Sb}^{+}$were crossed back to TM3 $r y^{R K} / r y^{506}$ females to create a balanced stock. Progeny from individual males were tested for the presence of the mus $309^{D 3}$ allele by the crossing of males to st mus $309^{D 2} / T M 3$ $\mathrm{Sb}$ Ser females and testing for sensitivity to killing by MMS as described (Boyd et al. 1976). The presence of $\Delta 2-3(99 \mathrm{~B}$ ) was verified by the crossing of males to $y n^{w}$ females, and scoring $\mathrm{Sb}^{+}$ male progeny for a mosaic bristle pattern, indicating the presence of transposase. The $w^{1118}$ chromosome was introduced by the crossing of mus $309^{D 3}$ ry $د 2-3(99 \mathrm{~B}) / T M 3$ males to $w^{1118}$; $T M 3$ CXD females and the crossing of white-eyed, $\mathrm{Sb}$ males to $r y^{*}, \mathrm{Sb}$ females, and selection of only white-eyed, Sb progeny in subsequent generations. For the control crosses, isogenic $w^{1118}$; $12.3 \mathrm{Ki} \mathrm{P} P^{T} /$ TM3 males were used for mus309/t, and $\mathrm{w}^{1118}$; mus $309^{12.3}$ ry $/$ TM3 males were used for "without $\Delta 2-3$ " (see Fig. 1B). Each was made from non- $W^{1118}$ stocks with the $w^{1118}$; TM3 CXD stock as described above such that the stocks are isogenic except for the non-TM3 third chromosome.

The $y n^{\prime \prime} / F M 7 a$; st mus $309^{l 22} / T M 3$ stock used in the assay was made as follows: y $s n^{\text {w }}$ females were crossed to $F M 7 a$ males, and $y s n^{w / F M 7 a}$ female progeny crossed to $y s n^{w}$; TM3/ $C X D$ males. y $s n^{w / F M 7 a}$; TM3 females were crossed to $y s n^{w}$; $C X D$ males to create $y s n^{w} / F M 7 a ; T M 3 / C X D$. Females from this stock were crossed to st mus $309^{D 2} / T M 3$ Sb Ser males, and yellow, $\mathrm{sn}^{\mathrm{w}}, \mathrm{Sb}$, non-CxD males crossed back to y $s n^{w} / F M 7 a$; $T M 3$ CXD females. non- $C x D$ progeny were mated to create the y $s n^{w / F M 7 a}$; st mus309 $22 / T M 3$ balanced stock.

In the assay, crosses were performed with five males and five virgin females per vial. Typically, 10-15 vials for each experimental cross were tested, and progeny scored until 17 days after initiation of the cross. All classes of progeny were scored. The male or female survival was determined as the ratio of male or female mus309 mutant progeny that had undergone P-element mobilization to mus $309 /$ + female progeny that lacked the $s n^{w}$ chromosome as depicted in Figure 1B. Standard deviations were calculated for each cross that was performed at least two times.

\section{Female fertility and MMS assays}

To test the transformant strains for complementation of the heteroallelic mus309 mutant phenotypes, two or three independent $\mathrm{X}$ or second chromosome-located transgenic lines were crossed to $\mathrm{W}^{1118}$; TM3/CXD to establish $\mathrm{w}^{118} ; \mathrm{P}\left[\mathrm{w}^{+}, \mathrm{IRBP}\right]$; $T M 3 / C \times D$ stocks. These lines were crossed to $w^{1118} ;$ mus $309^{D 3}$ ry/TM3 and $w^{+}$, Sb progeny selected and crossed to establish $\mathrm{w}^{1118} ; \mathrm{P}\left[\mathrm{w}^{+}, \mathrm{IRBP}\right] ;$ mus $309^{D 3} \mathrm{ry} / \mathrm{TM} 3$ balanced stocks.

To test for rescue of female fertility, $\left.\mathrm{w}^{1118} ; \mathrm{P} \mid \mathrm{w}^{+}, \mathrm{IRBP}\right]$; mus $309^{D .3}$ ry/TM3 males were crossed to $\mathrm{w}^{1118}$; st mus $309^{D 2}$, $T M 3$ females, and $w^{+}, \mathrm{Sb}^{+}$females crossed, individually, to three $w^{1118}$ males. For each transformant tested, 100 crosses were performed and fertility scored by the presence of larvae in the vial. Isogenic control crosses with strains lacking an ectopic copy of IRBP were also performed.

To test for rescue of MMS sensitivity, $15 \mathrm{w}^{1118} ; \mathrm{P}\left[\mathrm{w}^{+}, \mathrm{IRBP}\right]$; mus $309^{123}$ ry/TM3 males were crossed to $15 \mathrm{w}^{1118}$; st mus $309^{122} / T M 3$ aged females and the flies allowed to lay for 48 $\mathrm{hr}$ before being removed to a fresh vial. After 69-72 hr, mutagen was applied to the food and the progeny allowed to develop at $25^{\circ} \mathrm{C}$. All classes of progeny were scored until 17 days after the cross was initiated. Siblings lacking an IRBP transgene were counted as the control class. Percent survival was determined as the number of heteroallelic mus 309 mutant progeny either with or without an IRBP-containing transgene relative to their respective mus $309^{D 2}$ or ${ }^{D 3} / T M 3$ siblings $\times 100$.

\section{P-element excision assay}

The plasmids pISP- $2 / \mathrm{Km}(0.5 \mathrm{mg} / \mathrm{ml}), \mathrm{pBSKS}(+)$ PAc KP-S $\Delta 2-3$ $\{0.25 \mathrm{mg} / \mathrm{ml})$, and $\mathrm{pBSKS}(+\mid$ PAc IRBP $(0.25 \mathrm{mg} / \mathrm{ml})$ were injected either alone or in combination into preblastoderm embryos. The injected embryos were incubated at $18^{\circ} \mathrm{C}$ in oxygensaturated oil for 20-22 hr. Embryos were washed with heptane to remove the oil and transferred to $1.5-\mathrm{ml}$ Eppendorf tubes. Plasmid DNA was recovered as described (Rio et al. 1986; O'Brochta and Handler 1988) and resuspended in $10 \mathrm{~mm}$ Tris- 
$\mathrm{HCl}, 1$ mM EDTA (pH 7.5). Thirty-five embryo equivalents were used to transform $60 \mu \mathrm{l}$ of the RecA ${ }^{-}$Escherichia coli strain AG1574 (Kaufman and Rio 1992) by electroporation with a BioRad Gene Pulser as described by the manufacturer. Cells were plated onto Luria broth (LB) plates containing $100 \mu \mathrm{g} / \mathrm{ml}$ of ampicillin or LB plates containing $100 \mu \mathrm{g} / \mathrm{ml}$ of ampicillin and $50 \mu \mathrm{g} / \mathrm{ml}$ of kanamycin. Colonies were allowed to develop for $12-16 \mathrm{hr}$ at $37^{\circ} \mathrm{C}$. Plasmid DNA was isolated from single $\mathrm{Amp}^{\mathrm{R}}$ $\mathrm{Kan}^{\mathrm{R}}$ colonies and analyzed by restriction endonuclease cleavage and chain-termination sequencing with Sequenase 2.0 (U.S. Biochemical) according to the manufacturer's instructions. The primer used for sequencing was $5^{\prime}$-CCGGCTCGTATGTTGTGTGG-3'.

\section{Acknowledgments}

We thank M. Botchan, K. Collins, N. Cozzarelli, G. Rubin, and members of our laboratory for critical comments. We also thank the Boyd laboratory (University of California, Davis) for providing the mus $309^{D 2}$ and mus $309^{D 3}$ alleles. This work was supported by a grant from the National Institutes of Health (R01GM48862).

The publication costs of this article were defrayed in part by payment of page charges. This article must therefore be hereby marked "advertisement" in accordance with 18 USC section 1734 solely to indicate this fact.

\section{References}

Aboussekhra, A., M. Biggerstaff, M.K.K. Shivii, J.A. Vilpo, V Moncollin, V.N. Podust, M. Protic, U. Hübscher, J.-M. Egly, and R.D. Wood. 1995. Mammalian DNA nucleotide excision repair reconstituted with purified protein components. Cell 80: 859-868.

Akroyd, J.E., E. Clayson, and N.P. Higgins. 1986. Purification of the gam gene-product of bacteriophage $\mathrm{Mu}$ and determination of the nucleotide sequence of the gam gene. Nucleic Acids Res. 14: 6901-6914.

Ashburner, M. 1989. Drosophila: A laboratory manual. Cold Spring Harbor Laboratory Press, Cold Spring Harbor Laboratory, NY.

Bainton, R., P. Gamas, and N.L. Craig. 1991. Tn7 transposition in vitro proceeds through an excised transposon intermediate generated by staggered breaks in DNA. Cell 65: 805-816.

Banga, S.S., A. Velazquez, and J.B. Boyd. 1991. P transposition in Drosophila provides a new tool for analyzing postreplication repair and double-strand break repair. Mutat. Res. 255: 7988.

Bannister, A.J., T.M. Gottlieb, T. Kouzarides, and S.P. Jackson. 1993. c-Jun is phosphorylated by the DNA-dependent protein kinase in vitro; definition of the minimal kinase recognition motif. Nucleic Acids Res. 21: 1289-1295.

Beall, E.L., A. Admon, and D.C. Rio. 1994. A Drosophila protein homologous to the human p70 Ku autoimmune antigen interacts with the $\mathrm{P}$ transposable element inverted repeats. Proc. Natl. Acad. Sci. 91: 12681-12685.

Benjamin, H.W. and N. Kleckner. 1989. Intramolecular transposition by Tn10. Cell 59: 373-383.

Berg, D. 1989. Transposon Tn5. In Mobile DNA (ed. D.E. Berg and M.M. Howe), pp. 185-210. American Society for Microbiology Publications, Washington, D.C.

Blunt, T., N.J. Finnie, G.E. Taccioli, G.C.M. Smith, J. Demengeot, T. Gottlieb, R. Mizuta, A.J. Varghese, F.W. Alt, P.A. Jeggo, and S.P. Jackson. 1995. Defective DNA-dependent protein kinase activity is linked to $V(D) /$ recombination and DNA repair defects associated with the murine scid mutation. Cell 80: 813-823.

Boubnov, N.V., K.T. Hall, Z. Wills, S.E. Lee, D.M. He, D.M. Benjamin, C.R. Pulaski, H. Band, W. Reeves, E.A. Hendrickson, and D.T. Weaver. 1995. Complementation of the ionizing radiation sensitivity, DNA end binding, and $V(D) /$ recombination defects of double-strand break repair mutants by the p86 Ku autoantigen. Proc. Natl. Acad. Sci. 92: 890894.

Boyd, J.B. and R.B. Setlow. 1976. Characterization of postreplication repair in mutagen-sensitive strains of Drosophila melanogaster. Genetics 84: 507-526.

Boyd, I.B., M.D. Golino, T.D. Nguyen, and M.M. Green. 1976. Isolation and characterization of X-linked mutants of Drosophila melanogaster which are sensitive to mutagens. Genetics 84: 485-508.

Boyd, J.B., M.D. Golino, K.E.S. Shaw, C.J. Osgood, and M.M. Green. 1981. Third-chromosome mutagen-sensitive mutants of Drosophila melanogaster. Genetics 97: 607-623.

Brush, G.S., C.W. Anderson, and T.J. Kelly. 1994. The DNAactivated protein kinase is required for the phosphorylation of replication protein A during simian virus 40 DNA replication. Proc. Natl. Acad. Sci. 91: 12520-12524.

Cao, Q.P., S. Pitt, J. Leszyk, and E.F. Baril. 1994. DNA-dependent ATPase from HeLa cells is related to human $\mathrm{Ku}$ autoantigen. Biochemistry 33: 8548-8557.

Carty, M.P., M. Zernik-Kobak, S. McGrath, and K. Dixon. 1994. UV light-induced DNA synthesis arrest in HeLa cells is associated with changes in phosphorylation of human singlestranded DNA-binding protein. EMBO J. 13: 2114-2123.

Engels, W.R. 1979. Extrachromosomal control of mutability in Drosophila melanogaster. Proc. Natl. Acad. Sci. 76: 40114015.

- 1989. P elements in Drosophila. In Mobile DNA led. D.E. Berg and M.M. Howel, pp. 437-484. American Society of Microbiology, Washington, D.C.

Engels, W.R., D.M. Johnson-Schlitz, W.B. Eggleston, and I. Sved. 1990. High-frequency P element loss in Drosophila is homolog dependent. Cell 62: 515-525.

Falzon, M. and E.L. Kuff. 1992. The nucleotide sequence of a mouse cDNA encoding the $80-\mathrm{kD}$ subunit of the $\mathrm{Ku}(\mathrm{p} 70$ / p80) autoantigen. Nucleic Acids Res. 20: 3784.

Falzon, M., J.W. Fewell, and E.L. Kuff. 1993. EBP-80, a transcription factor closely resembling the human autoantigen $\mathrm{Ku}$, recognizes single- to double-strand transitions in DNA. $I$. Biol. Chem. 268: 10546-10552.

Feldmann, H. and E.L. Winnacker. 1993. A putative homolog of the human autoimmune $\mathrm{Ku}$ antigen from Saccharomyces cerevisiae. J. Biol. Chem. 268: 12895-12900.

Finnie, N.J., T.M. Gottlieb, T. Blunt, P.A. Jeggo, and S.P. Jackson. 1995. DNA-dependent protein kinase activity is absent in $x r s-6$ cells: implications for site-specific recombination and DNA double-strand break repair. Proc. Natl. Acad. Sci. 92: $320-324$.

Gottlieb, T.M. and S.P. Jackson. 1993. The DNA-dependent protein kinase: Requirement for DNA ends and association with $\mathrm{Ku}$ antigen. Cell 72: 1-20.

Jacoby, D.B. and P.C. Wensink. 1994. Yolk protein factor 1 is a Drosophila homolog of $\mathrm{Ku}$, the DNA-binding subunit of a DNA-dependent protein kinase from humans. J. Biol. Chem. 269: 11484-11491.

Jones, K.R. and G.M. Rubin. 1990. Molecular analysis of no-ontransient $\mathrm{A}$, a gene required for normal vision in Drosophila. Neuron 4: 711-723.

Karess, R.E. and G.M. Rubin. 1984. Analysis of P transposable 
element functions in Drosophila. Cell 38: 135-146.

Kaufman, P.D. and D.C. Rio. 1992. P-element transposition in vitro proceeds by a cut-and-paste mechanism and uses GTP as a cofactor. Cell 69: 27-39.

Kaufman, P.D., R.F. Doll, and D.C. Rio. 1989. Drosophila P element transposase recognizes internal $P$ element DNA sequences. Cell 59: 359-371.

Kirchgessner, C.U., C.K. Patil, J.W. Evans, C.A. Cuomo, L.M. Fried, T. Carter, M.A. Oettinger, and J.M. Brown. 1995. DNA-dependent kinase (p350) as a candidate gene for the murine SCID defect. Science 267: 1178-1183.

Kleckner, N. 1989. Transposon Tn10. In Mobile DNA (ed. D.E. Berg and M.M. Howel, pp. 227-268. American Society for Microbiology Publications, Washington, D.C.

Klemenz, R., U. Weber, and W.J. Gehring. 1987. The white gene as a marker in a new P-element vector for gene transfer in Drosophila. Nucleic Acids Res. 15: 3947-3959.

Knuth, M.W., S.I. Gungerson, N.E. Thompson, L.A. Strasheim, and R.R. Burgess. 1990. Purification and characterization of proximal sequence element-binding protein l, a transcription activating protein related to $\mathrm{Ku}$ and TREF that binds the proximal sequence element of the human Ul promoter. I. Biol. Chem. 265(29): 17911-17920.

Laski, F.A., D.C. Rio, and G.M. Rubin. 1986. Tissue specificity of Drosophila $\mathrm{P}$ element transposition is regulated at the level of mRNA splicing. Cell 44: 7-19.

Lees-Miller, S.P., Y-R. Chen, and C.W. Anderson. 1990. Human cells contain a DNA-activated protein kinase that phosphorylates simian virus $40 \mathrm{~T}$ antigen, mouse $\mathrm{p} 53$, and the human Ku autoantigen. Mol. Cell. Biol. 10: 6472-6481.

Lees-Miller, S.P., K. Sakaguchi, S.J. Ullrich, E. Apella, and C.W. Anderson. 1992. Human DNA-activated protein kinase phosphorylates serines 15 and 37 in the amino-terminal transactivation domain of human p53. Mol. Cell Biol. 12: 5041-5049.

Lees-Miller, S.P., R. Godbout, D.W. Chan, M. Weinfeld, R.S. Day, G.M. Barron, and J. Allalunis-Turner. 1995. Absence of p350 subunit of DNA-activated protein kinase from a radiosensitive human cell line. Science 267: 1183-1185.

Liu, V.F. and D.T. Weaver. 1993. The ionizing radiation-induced replication protein A phosphorylation response differs between Ataxia Telangiectasia and normal human cells. Mol. Cell Biol. 13: 7222-7231.

May, G., C. Sutton, and H. Gould. 1991. Purification and characterization of $\mathrm{Ku}-2$, an octamer-binding protein related to the autoantigen Ku. I. Biol. Chem. 266: 3052-3059.

Messier, H., T. Fuller, S. Mangal, H. Brickner, S. Igarashi, J. Gaikwad, R. Fotedar, and A. Fotedar. 1993. p70 lupus autoantigen binds the enhancer of the T-cell receptor $\beta$-chain gene. Proc. Nat1. Acad. Sci. 90: 2685-2689.

Mimori, T. and J.A. Hardin. 1986. Mechanism of interaction between Ku protein and DNA. I. Biol. Chem. 261: 1037510379.

Mimori, T., M. Akizuki, H. Yamagata, S. Inada, S. Yoshida, and M. Homma. 1981. Characterization of a high molecular weight acidic nuclear protein recognized by antibodies in sera from patients with polymitosis-scleroderma overlap. $J$. Clin. Invest. 68: 611-620.

Misra, S. and D.C. Rio. 1990. Cytotype control of Drosophila P element transposition: The $66 \mathrm{kD}$ protein is a repressor of transposase activity. Cell 62: 269-284.

Mullins, M.C., D.C. Rio, and G.M. Rubin. 1989. Cis-acting DNA sequence requirements for $P$ element transposition. Genes \& Dev. 3: 729-738.

O'Brochta, D.A. and A.M. Handler. 1988. Mobility of P elements in drosophilids and nondrosophilids. Proc. Natl.
Acad. Sci. 85: 6052-6056.

O'Brochta, D.A., S.P. Gomez, and A.M. Handler. 1991. P element excision in Drosophila melanogaster and related drosophilids. Mol. \& Gen. Genet. 225: 387-394.

O'Hare, K. and G.M. Rubin. 1983. Structure of P transposable elements and their sites of insertion and excision in the Drosophila melanogaster genome. Cell 34: 25-35.

Paillard, S. and F. Strauss. 1991. Analysis of the mechanism of interaction of simian Ku protein with DNA. Nucleic Acids Res. 19: 5619-5624.

Pan, Z.-Q., A.A. Amin, E. Gibbs, H. Niu, and J. Hurwitz. 1994. Phosphorylation of the p34 subunit of human singlestranded-DNA-binding protein in cyclin A-activated $G_{1}$ extracts is catalyzed by cdk-cyclin A complex and DNA-dependent protein kinase. Proc. Natl. Acad. Sci. 91: 83438347.

Pato, M.L. 1989. Bacteriophage Mu. In Mobile DNA led. D.E. Berg and M.M. Howel, pp. 23-52. American Society for Microbiology Publications, Washington, D.C.

Peterson, S.R., A. Kurimasa, M. Oshimura, W.S. Dynan, E.M. Bradbury, and D.J. Chen. 1995. Loss of the catalytic subunit of the DNA-dependent protein kinase in DNA doublestrand-break-repair mutant mammalian cells. Proc. Natl. Acad. Sci. 92: 3171-3174.

Rasmusson, K.E., J.D. Raymond, and M.J. Simmons. 1993. Repression of hybrid dysgenesis in Drosophila melanogaster by individual naturally occurring $\mathrm{P}$ elements. Genetics 133: 605-622.

Rathmell, W.K. and G. Chu. 1994. Involvement of the Ku autoantigen in the cellular response to DNA double-strand breaks. Proc. Natl. Acad. Sci. 91: 7623-7627.

Reeves, W. 1992. Antibodies to the $\mathrm{p} 70 / \mathrm{p} 80(\mathrm{Ku})$ antigens in systemic lupus erythematosus. Rheum. Dis. Clin. North Am. 18: 391-415.

Reiss, B., R. Sprengel, and H. Schaller. 1984. Protein fusions with the kanamycin resistance gene from transposon $\operatorname{Tn} 5$. EMBO 1. 3: 3317-3322.

Rio, D.C. and G.M. Rubin. 1988. Identification and purification of a Drosophila protein that binds to the terminal 31-basepair inverted repeats of the $\mathrm{P}$ transposable element. Proc. Natl. Acad. Sci. 85: 8929-8933.

Rio, D.C., F.A. Laski, and G.M. Rubin. 1986. Identification and immunochemical analysis of biologically active Drosophila P element transposase. Cell 44: 21-32.

Rio, D.C., G. Barnes, F.A. Laski, J. Rine, and G.M. Rubin. 1988. Evidence for Drosophila P element transposase activity in mammalian cells and yeast. J. Mol. Biol. 200: 411-415.

Robertson, H.M., R.W. Preston, D.M. Phillis, W.K. JohnsonSchlitz, and W.R. Engels. 1988. A stable genomic source of $\mathrm{P}$ element transposase in Drosophila melanogaster. Genetics 118: $461-470$.

Roiha, H., G.M. Rubin, and K. O' Hare. 1988. P element insertions and rearrangements at the singed locus of Drosophila melanogaster. Genetics 119: 75-83.

Rorth, P. 1994. Specification of C/EBP function during Drosophila development by the bZIP basic region. Science 266: $1878-1881$

Saedler, H. and P. Nevers. 1985. Transposition in plants: A molecular model. EMBO /. 4: 585-590.

Satoh, M., J. Wang, and W.H. Reeves. 1995. Role of the p70 (Ku) subunit in posttranslational stabilization of newly synthesized p80 during DNA-dependent protein kinase assembly. Eur. I. Cell Biol. 66: 127-135.

Spradling, A.C. 1986. P element-mediated transformation. In Drosophila: A practical approach (ed. D.B. Roberts), pp. 175197. IRL Press, Oxford, UK. 
Spradling, A.C. and G.M. Rubin. 1983. The effect of chromosomal position on the expression of the Drosophila xanthine dehydrogenase gene. Cell 34: 47-57.

Staveley, B.E., T.R. Heslip, R.B. Hodgetts, and J.B. Bell. 1995. Protected $P$ element termini suggest a role for inverted-repeat-binding protein in transposase-induced gap repair in Drosophila melanogaster. Genetics 139: 1321-1329.

Taccioli, G.E., T.M. Gottlieb, T. Blunt, A. Priestley, J. Demengeot, R. Mizuta, A.R. Lehmann, F.A. Alt, S.P. Jackson, and P.A. Jeggo. 1994. Ku80: Product of the XRCC5 gene and its role in DNA repair and $\mathrm{V}(\mathrm{D} \mid \mathrm{J}$ recombination. Science 265: 1442-1445.

Takasu-Ishikawa, E., Y. Yoshihara, and Y. Hotta. 1992. Extra sequences found at $\mathrm{P}$ element excision sites in Drosophila melanogaster. Mol. \& Gen. Genet. 232: 17-23.

Thaler, D.S., M.M. Stahl, and F.W. Stahl. 1987. Evidence that the normal route of replication-allowed Red-mediated recombination involves double-chain ends. EMBO /. 6: $3171-$ 3176.

Tuteja, N., R. Tuteja, A. Ochem, P. Taneja, N.W. Huang, A. Simoncsits, S. Susic, K. Rahman, L. Marusic, J. Chen, J. Zhang, S. Wang, S. Pongor, and A. Falaschi. 1994. Human DNA helicaselI: A novel DNA unwinding enzyme identified as the Ku autoantigen. EMBO I. 13: 4991-5001.

Vogel, E. and A.T. Natarajan. 1979. The relation between reaction kinetics and mutagenic action of monofunctional alkylating agents in higher eukaryotic systems I. Recessive lethal mutations and translocation in Drosophila. Mutat. Res. 62: $51-100$.

Wang, J., M. Satoh, C.H. Chou, and W.H. Reeves. 1994. Similar DNA binding properties of free $\mathrm{p} 70(\mathrm{Ku})$ subunit and $\mathrm{p} 70 /$ p80 heterodimer. FEBS Lett. 351: 219-224. 


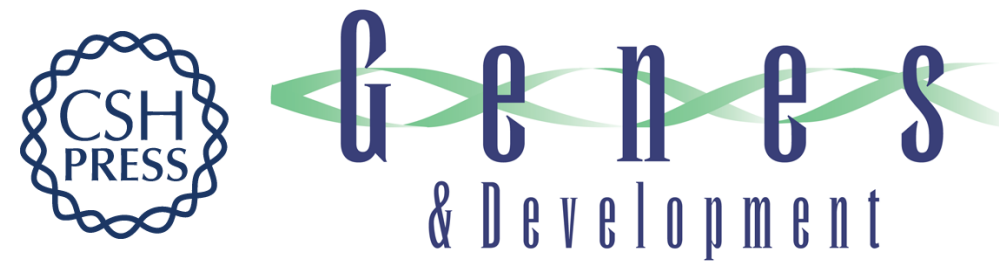

\section{Drosophila IRBP/Ku p70 corresponds to the mutagen-sensitive mus309 gene and is involved in P-element excision in vivo.}

E L Beall and D C Rio

Genes Dev. 1996, 10:

Access the most recent version at doi:10.1101/gad.10.8.921

References This article cites 67 articles, 31 of which can be accessed free at: http://genesdev.cshlp.org/content/10/8/921.full.html\#ref-list-1

License

Email Alerting

Receive free email alerts when new articles cite this article - sign up in the box at the top Service right corner of the article or click here.

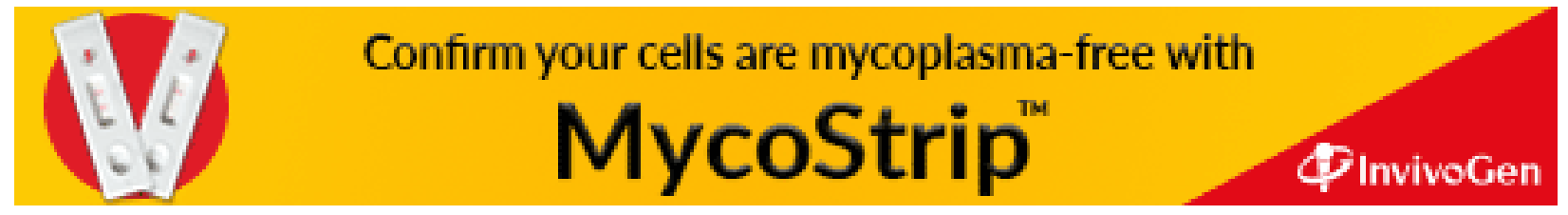

